\title{
Good Environmental Governance on Waste Management: An Instrument of Promoting Sustainable Development Goals
}

\author{
Sri Wahyu Wijayanti ${ }^{1}$, Salma Azzahra ${ }^{2}$ \\ \{sriwijayantih12@gmail.com¹,s.salmaazzahra@gmail.com² \\ National Institute of Public Administration ${ }^{1}$ \\ Universitas Indonesia ${ }^{2}$
}

\begin{abstract}
The 11th goal of the SDGs is sustainable cities and communities, one of the targets is to improve waste management. Waste is one of the problems experienced by DKI Jakarta. It is caused by development, consumptive culture, and technology, where the largest contributor is households. Waste management requires cooperation and good environmental governance (GEG). The method used for this research is descriptive-qualitative, data obtained from news, journals, and institutional publications. The results of the study indicate that the dimension of the rule of law has been fulfilled by the existence and regulations, however it is not sufficient because it has not been able to improve the system. In terms of participation and representation, the government has involved the public and the private sector, although it still needs improvement, the same goes for transparency and accountability, and access to obtain justice. In terms of access to information, socialization has not yet reached the grassroots level. In the decentralization dimension, the Government needs to improve the strategies they take to achieve integrated and inclusive waste management. On the institutional dimensions, the Government has an Environmental Service (DLH) and cooperates with other institutions in managing waste, such as the Bekasi City Government.
\end{abstract}

Keywords: SDGs; good environmental governance; waste management; DKI Jakarta

\section{Introduction}

Garbage is one of the problems experienced by big cities, including Jakarta (Verawati and Tuti, 2020). Problems related to waste in Jakarta are the increasing amount of waste, insufficient waste management, and poor hygiene culture (Verawati and Tuti, 2020). Waste is defined as material or residual substances from human activities and/or natural processes that are unwanted and no longer have a use or purpose, so they need to be disposed of (Asiyah, 2019). The paradigm of waste management based on final disposal must be changed to a view of waste as a resource that has economic value and can be utilized. The largest solid waste contributor in Indonesia comes from households, where on average one household in Jakarta produces $1.32 \mathrm{~kg}$ of waste per day (Aprilia et al, 2013). 
Based on research conducted by Aprilia et al (2013), as much as 50\% of the waste is waste, $14 \%$ is plastic waste, $12 \%$ is paper waste, while food consists of metal, diapers, glass, and so on. The problem that arises is the low awareness of the community to separate waste based on its type. In fact, segregating waste by type can facilitate waste management. Organic waste (food waste, plant waste, and wood) can be processed into fertilizer, while inorganic waste (plastic and paper) can be recycled. As for hazardous waste is waste that contains hazardous substances such as oil, paint, and electronic devices (Aprilia et al, 2013).

Regulating these problems, the Indonesian government has issued several regulations, one of which is the regulation of the Ministry of Public Works and Public Housing No.21/PRT/M/2006 which initiates several strategies. The first strategy is to increase public awareness about the $3 \mathrm{Rs}$ (reduce, reuse, and recycle). Another strategy is to increase cooperation and coordination among stakeholders. Inter-institutional cooperation is needed for cross-sectoral issues, such as with product manufacturers, as well as industrial sectors that can treat waste. The Jakarta government has collaborated with manufacturers that produce products that can produce hazardous waste to provide waste storage and processing facilities. However, there are no regulations regarding the transportation of waste from households to this facility, so the homeowner is responsible for its delivery (Aprilia et al, 2013).

Several factors causing the continued development of the waste problem are development, consumptive culture and technological developments (Verawati and Tuti, 2020), so that the government cannot handle it alone. In fact, development and development that are not managed properly are a disturbance to the environmental balance (Supriyani in Nopiyandri, 2014). Collaborative action is needed between the government and other stakeholders to solve problems. Several actors involved in handling waste problems are the government, the community, and the private sector as well as community institutions through waste banks (Nugroho, 2015).

Therefore, good environmental governance is needed to obtain effective synergies so that they can provide the best solutions for various environmental problems, including waste problems. The implementation of good environmental governance has been recommended by the Ministry of Environment and Forestry (Nugroho, 2015). Mustaghfiroh et al (2020) explain that environmental governance refers to how to manage and interact with and in the environment in real terms and focuses on the reciprocal relationship between ecosystems and social systems. This paper aims to look at the implementation of good environmental governance in waste management in DKI Jakarta.

\section{Good Environmental Governance}

Good governance is one of the tools that can be used to achieve a healthier government by paying attention to transparency, accountability, participation, legal empowerment, effectiveness and efficiency, and justice (Nopiyandri, 2014). Meanwhile, good environmental governance is part of good governance that emphasizes environmental sustainability and sustainability (Mustagfiroh et al, 2020). Siahaan (in Mustagfiroh et al, 2020) states that in order to carry out the principles of good governance, it is necessary to pay attention to environmental management. The World Bank is of the opinion that all activities that aim to protect the environment and the successful use of natural resources in a sustainable manner are part of good environmental governance.

Rustan and Sari (2009) mention three components of governance, namely public governance (government), corporate governance (private sector), and civil society (civil society). The 
relationship between these three actors must be balanced and mutually supervise. Balbase (Mustaghfiroh at al, 2020) have seven principles good environmental governance, including the rule of law, participation and representation, access to information, transparency and accountability, decentralization, institutions and institutions, and access to justice. Meanwhile, the Indonesian Center for Environment Law (ICEL) formulated six principles of good environmental governance (GEG), including empowerment, community involvement and public access to information; transparency; democratic decentralization; recognition of the carrying capacity of ecosystems and sustainability; recognition of indigenous peoples and local communities; and enforcement power (Nugroho, 2015).

\section{Existing Condition of Waste Management in Jakarta}

Indonesia has been involved in several international programs aimed at handling waste, including the Basel Convention in 1993 and the Tokyo Protocol in 2004. This shows that the government has realized the threat of waste problems and their impact on the environment. However, efforts taken by the government on a national and local scale still need to be increased. In fact, the new law governing waste and explaining the concepts, objectives, and handling actions was only published in 2007 (Mediana, 2010).

Waste management in Jakarta is regulated in several regulations, one of which is Regional Regulation (Perda) no. 3 of 2013, which was later changed to Perda no. 4 of 2019 concerning Amendments to Regional Regulation no. 3 of 2013 concerning Waste Management. This fulfills the legal aspect of the GEG which states the existence of binding rules as one of the components of the GEG. However, ICEL assessed that the regulation only serves to add provisions for the construction of an intermediate treatment facility (ITF), but still does not improve the waste management and waste reduction system (ICEL, 2019). The existence of a regional regulation and a waste processing agency belonging to the DKI Jakarta Provincial Government shows that the normative aspect of decentralization in GEG is fulfilled. However, in practice there are some things that need to be improved.

Reported by kompas.com, data from the DKI Jakarta Environmental Service shows that the majority of waste comes from households, which is around $60 \%$, then $29 \%$ comes from commercial areas, and $11 \%$ comes from public facilities, where Jakarta produces 7,500 tons per day. garbage (Marison, 13 June 2019). However, the government has not been able to process all of the waste, so the community must manage it themselves. This causes several types of improper waste management, such as burning, burial, and dumping into rivers. The Indonesian Ministry of Industry (in Mediana, 2010) noted that $40.9 \%$ of waste was processed through final disposal (TPA), $35.49 \%$ through burning, $7.54 \%$ buried, $15.27 \%$ dumped into roads or rivers, while the recycled reset is only $1.61 \%$.

KLHK data for 2019 shows that the percentage of unmanaged waste in DKI Jakarta is smaller than other Jabodetabek areas. However, the number is still much larger. The percentage of unmanaged waste in West Jakarta is $2.4 \%$ from $1,946.77$ tons per day, South Jakarta $1.68 \%$ from 1,631 tons per day, North Jakarta 1.8\% from 1,323.12 tons per day, Central Jakarta $0 \%$ from 839.45 tons per day, and East Jakarta $12.39 \%$ from 2,253.66 tons per day. Waste that is not managed and released into the environment is 377.16 tons per day (Zulfikar, January 27, 2020). In processing waste, the Provincial Government (Pemprov) of DKI Jakarta has issued a Master Draft for Waste 
Processing (RIPS) for 2012-2032, which later became part of Perda no. 3 of 2013 concerning Waste Management.

Furthermore, the Regional Medium Term Program Plan (RPJMD) 2017-2022 was issued which in waste management also refers to the RIPS. This RPJMD regulates waste management with a new approach, namely by reducing and handling waste. This is done to reduce the garbage that accumulates in the TPST. Waste reduction is carried out using the 3R method, namely reducing waste, reusing, and recycling. In implementing the 3Rs, the government cannot act alone, but requires the participation and active role of the community. The government sets a target for achieving waste management. As for the handling, which includes the process of sorting, collecting, transporting, processing, and final processing, it is mostly done by local governments. In 2017, the waste reduction performance in Jakarta was $13.09 \%$ of the $15 \%$ target, in 2018 it was $12.40 \%$ of the $14 \%$ target, and in 2019 it was $17 \%$ of the $17 \%$ target. Meanwhile, for waste management there was a decline in the $2017-2019$ period, with 2017 reaching $86.91 \%$ in $2017,87.6 \%$ in 2018 and $82.94 \%$ in 2019 (Zulfikar, 27 January 2020).

In 2014, there were 801 garbage trucks available, but 510 of them were unfit for use (Liauw, 1 April 2014). The DKI Jakarta Provincial Government has collaborated with the private sector to transport waste, around $67 \%$ of the transportation is carried out by the private sector. However, due to the poor service provided by the private sector, the government decided to terminate the contract and transport Jakarta's waste itself. However, the number is still not sufficient (Brahmanti, 2016). The current TPST for DKI Jakarta is the Bantargebang TPST which has been carried out since 1989. The estimated waste coming from Jakarta to Bantargebang is 7,000 to 8,000 tons per day and carried by 1,200 garbage trucks (Sukwika and Noviana, 2020).

Currently, Bantargebang's capacity is approaching its maximum and it is estimated that it will no longer be able to accommodate waste in 2021 (Sukwika and Noviana, 2020). The maximum capacity of Bantargebang is 49 million tons and there are only about 10 million tons left. In addition, waste management with an open dumping system has also reached a height of 35 meters. To reduce this, TPST Bantargebang did several things, namely forming a composting house and waste bank in collaboration with several stakeholders.

\section{The role of actors in waste management in Jakarta}

To see the dimensions of participation in good environmental governance, it is necessary to examine each of the actors involved in waste management in Jakarta.

\section{Government}

Initially, waste management was the responsibility of several institutions, such as the Ministry of Public Works and Public Housing (PUPR), the Ministry of Home Affairs (Kemendagri), the Ministry of Health (Kemenkes), the Agency for the Assessment and Application of Technology (BPPT), the Environmental Impact Management Agency (BAPEDAL). ), and Sub-Directorate of Waste Management (Mediana, 2010). However, this involvement causes overlapping responsibilities, poor implementation, law enforcement and waste management regulations.

In subsequent developments, the institutions involved in waste management are KLHK and PUPR at the national level (Mediana, 2010), in which KLHK is responsible for policy development, formulation of regulations, and coordination efforts in pollution control, while PUPR is responsible 
for providing technical guidance, promote pilot projects, and oversee large-scale activities. Meanwhile, at the regional level, Jakarta has the DKI Jakarta Environmental Agency (DLH).

DLH is a form of fulfillment of one of the components of GEG, namely the institutional and institutional aspects. In the 2017-2022 RPJMD, the role of the DKI Jakarta DLH is to provide information, communication, and socialization to the public regarding the $3 \mathrm{R}$ program which is part of the Joint Responsibility Waste Movement (Samtama). Samtama is a program intended to reduce and manage waste from Prayoa sources, namely households and communities by changing their mindset (Prayoga, 25 August 2019). In addition, DLH DKI Jakarta also plays a role in fostering waste banks, the Adiwiyata school program, and fostering composting.

In carrying out its role related to the $3 \mathrm{R}$ program and waste bank, DKI Jakarta DLH socializes the program to sub-districts, schools, and Family Welfare Empowerment (PKK). However, in Verawati and Tuti's (2020) research, it is evident that there are still many people who do not know about the two programs. The community admitted that they did not receive socialization, and the ongoing recycling activities were the community's own initiative. The socialization only reached the kelurahan level but did not reach smaller neighborhoods.

So far, the efforts made by the DKI Jakarta Provincial Government regarding the waste problem are planning for the provision of ITF and the construction of a waste power plant (PLTSa) (Sukwika and Noviani, 2020). In providing ITF, the DKI Provincial Government cooperates with DKI Jakarta DLH, BUMD PT Jakarta Propertindo and Perumda Sarana Jaya. The ITF is planned to be able to process 2,000 to 2,200 tons of waste per day and generate up to 35 megawatts of electricity (BPK, 2020). In practice, until now the construction of the ITF has not continued and has stalled, even though the program maturation process has been completed in 2017.

In addition, another criticism that arises is the unbalance of costs incurred by the government with the amount of electricity that can be converted from waste (Hana, 23 February 2021). For the second effort, namely PLTSa, the cooperation document between the DKI Provincial Government and BPPT was signed in 2017 and has been operational in 2019. In 2020, PLTSa Merah Putih succeeded in converting 9,879 tons of waste into $783.63 \mathrm{MWh}$. The results from the combustion of PLTSa are also used as paving blocks and in the same year, 29,263 units have been produced (Wiryono, March 9, 2021).

In the Government Regulation of the Republic of Indonesia Number 81 of 2012 concerning the Management of Household and Similar Waste, it is regulated regarding the Integrated Waste Management Site (TPST) which is the place for collecting, sorting, reusing, recycling, processing, and final processing of waste (Brahmati, 2016). ). The TPST for DKI Jakarta is the Bantargebang TPST which is managed in collaboration with the Bekasi City Government (Sukwika and Noviana, 2020). This agreement is regulated in the Amendment Agreement of the cooperation agreement between the DKI Jakarta Provincial Government and the Bekasi City Government No. 25 of 2016 and No. 444 of 2016 (Larasati and Puspaningtyas, 2020).

When viewed from the institutional and institutional aspects of GEG, some of the problems faced by the Jakarta waste management implementing agencies include refusal from the community, demands for tipping fees, the polemic of subsidized diesel fuel, infrastructure corruption by the Bekasi City Government, and the burning of the DKI Regional Government garbage trucks. Jakarta (Mulyadin et al., 2018). Larasati and Puspaningtyas (2020) found that the number of residents of DKI Jakarta and Bekasi served in waste management at PTST Bantargebang only reached 35\%, even though the minimum criteria is two personnel for every 100 people. 
In addition, several conflicts were found in operating the Bantargebang TPST, including with private companies that process PTST, the Bekasi City Government (Pemkot), and the DKI Jakarta and Bekasi DPRD. As research conducted by Mulyadin et al (2018), the conflict that occurred between the DKI Provincial Government and PT Godang Tua Jaya as the manager of the Bantargebang TPST was caused by the lack of income received by PT Godang Tua Jaya and the PT's negligence in building an incinerator and gasification landfill anaerobic digestion which ultimately resulted in the termination of the contract.

The second conflict with the Bekasi City Government is regarding the tipping fee received by the Bekasi City Government. The Bekasi City Government said that they only received IDR 49.5 billion, while in the calculations of the DKI Jakarta Provincial Government, the Bekasi City Government received IDR 54.8 billion. The conflict with the DKI Jakarta DPRD is that the DPRD considers that the DKI Jakarta Provincial Government will find it difficult to manage waste alone without the assistance of the private sector after the termination of the contract with PT Godang Tua Jaya.

Finally, the conflict with the Bekasi DPRD was caused by the prohibition of passing for Jakarta garbage trucks because they were considered to have violated the standardization of garbage trucks, routes, and operating hours. In addition, the Bekasi DPRD considers that the DKI Jakarta Provincial Government has broken the agreement to build an artesian well as well as to provide health assistance for the community around PTST Bantargebang. In the dimensions of transparency and accountability at GEG, some descriptions of the conflicts that occurred can show that the dimensions have not been fulfilled properly. The difference in the calculation of the tipping fee between the DKI Jakarta Provincial Government and the Bekasi City Government indicates a data discrepancy that may indicate corruption of Rp5.3 billion.

In addition, another indication of corruption occurred in the case of PT Godang Tua Jaya which through its report showed that the amount of waste they managed did not increase, but the tipping fee given by the DKI Jakarta Provincial Government continued to rise (Faqih, 27 February 2014).

\section{Citizen}

The contribution of the community in waste management is realized in the form of a waste bank and $3 \mathrm{R}$ program. The waste bank is a waste management concept by teaching people to sort their waste, so that it can give more economic value to the waste. In the waste bank, household waste is divided into two categories, namely organic and non-organic. Organic waste is made into compost, while non-organic waste is further divided into three categories, namely plastic, paper, bottles, and metal (Meutia, 2017).

Based on the Regulation of the Ministry of Environment and Forestry Number 13 of 2012 concerning Guidelines for Implementing the Reduce, Reuse and Recycle Strategy with the Waste Bank, the Waste Bank is one of the central government programs that aims to reduce the volume of waste transported by TSPT. The initiative of the waste recycling group at the level of the neighborhood (RW) and neighborhood associations (RT). The majority of households that are members of this movement are families with middle to lower economics and consist of housewives who do not have jobs.

The level of participation is also still low. Handyanti (2016) explained that out of 700 households, only 336 people participated. The activities carried out are making compost and souvenirs. In contrast to Hadayanti's research, Nugraha et al (2018) found that in the establishment 
and operation of the South Jakarta Rajawati Garbage Bank, residents participated either directly or indirectly, by going into the waste bank or doing the 3 Rs in their daily life. This shows that some residents of Jakarta have begun to pay attention to environmental sustainability.

In general, households tend not to separate hazardous and non-hazardous waste when disposing of it. The low level of awareness makes many households dispose of hazardous and toxic waste along with other household waste (Aprilia et al, 2013; Verawati and Tuti, 2020). Waste4Change shows that $90 \%$ of the community still does not know about waste management (Yuliani, 2018). This low awareness is caused by the lack of socialization and complete information regarding the urgency of separating waste to the community (Verawati and Tuti, 2020).

In the dimension of access to information at GEG, it can be seen that not all of the required information has touched the community. The community also complained that the authorities did not provide concrete information regarding the rules and obligations to sort waste before it was disposed of. This shows the commitment of the government and the community to support the implementation of good waste management. Another problem that arises is that in some areas in Jakarta, the level of urbanization is high, and many people only live temporarily, so socialization needs to be done frequently (Aprilia et al., 2011).

Community involvement is voluntary and there is no incentive to participate. As a result, households with middle to upper socio-economic conditions are rarely involved in waste processing, while households that have been involved also rethink their involvement because the economic results received are not much. Difficulties were found in marketing and selling handicrafts produced from recycled waste because people were still reluctant to use them (Aprilia et al., 2011).

The current situation is that the community still manages waste using an end-of-pipe system, namely waste is collected, transported, and disposed of to the TPST.

a. Non-governmental organizations (NGOs) also play a role in dealing with the waste problem.

For example, Greenpeace which is an international organization to protect the environment and peace. Greenpeace is holding a campaign to raise public awareness about the ongoing waste problem (Krisyanti et al., 2020). This campaign can increase public awareness, as Krisyanti et al's research (2020) shows that the Abstinence Plastic campaign has succeeded in adding insight and other knowledge about waste. DLH DKI Jakarta lists several NGOs and communities that have contributed to waste management.

Among others, Generation Indonesia (GI) introduced a waste management program at the household level by means of composting, waste reduction, and other activities that generate economic value (GI, 2015). Not only running various programs, but NGOs also act as government supervisors. For example, the Indonesian Forum for the Environment (Walhi) urged the provincial government to immediately implement regulations prohibiting the use of plastic (Lova, August 13, 2019).

b. Scavenger

In waste processing, the components that come from the community are not only households and NGOs, but also scavengers. At PTST Bantargebang, scavengers are legalized to participate in recycling inorganic waste (Permatasari and Rahdriawan, 2013). Male scavengers work on sorting, packaging, buying and selling, cutting, transporting, and drying waste. Meanwhile, female scavengers usually only sort the garbage, although it was found that they were also scavenging the garbage. 
In addition, it was found that school-age children who also work at PTST, some of them are still in school, but there are also those who stop or do not go to school (Permatasari and Rahadriawan, 2013; Sasaki et al., 2014). The problems commonly faced by scavengers are poor social, economic and health conditions. The abundance of insects, contaminated groundwater, and medical waste and sharp objects can harm scavengers. Many scavengers suffer from respiratory tract infections and skin problems, to overcome this, the DKI Provincial Government provides compensation in the amount of money, in 2013 the amount of compensation given was Rp. 300,000 per three months (Permatasari and Rahadriawan, 2013), while in 2018 it was Rp. IDR 600,000.

There are sometimes problems in the distribution, such as in 2018, it was recorded that a number of residents demanded their rights because they were not given the compensation money (Nugroho, 16 May 2018). In waste processing, the components that come from the community are not only households and NGOs, but also scavengers. At PTST Bantargebang, scavengers are legalized to participate in recycling inorganic waste (Permatasari and Rahdriawan, 2013). Male scavengers work on sorting, packaging, buying and selling, cutting, transporting, and drying waste. Meanwhile, female scavengers usually only sort the garbage, although it was found that they were also scavenging the garbage.

In addition, it was found that school-age children who also work at PTST, some of them are still in school, but there are also those who stop or do not go to school (Permatasari and Rahadriawan, 2013; Sasaki et al., 2014). The problems commonly faced by scavengers are poor social, economic and health conditions. The abundance of insects, contaminated groundwater, and medical waste and sharp objects can harm scavengers. Many scavengers suffer from respiratory tract infections and skin problems, to overcome this, the DKI Provincial Government provides compensation in the amount of money, in 2013 the amount of compensation given was Rp. 300,000 per three months (Permatasari and Rahadriawan, 2013), while in 2018 it was Rp. IDR 600,000. There are sometimes problems in the distribution, such as in 2018, it was recorded that a number of residents demanded their rights because they were not given the compensation money (Nugroho, 16 May 2018).

Another problem that arises is that the efforts made to improve the welfare of scavengers are still not optimal, such as the absence of plastic waste cooperatives and adequate health facilities, and the emergence of social jealousy among scavengers due to the establishment of special zones for selected scavengers (Permatasari and Rahadriawan, 2013). In the GEG dimension, this shows that the aspect of access to justice is still not fully fulfilled. The government should pay more attention to the various parties involved and ensure that their welfare in processing waste is met. Moreover, the process of recycling and processing waste in developing countries is mostly carried out by scavengers (Medina in Sasaki et al., 2014).

c. Private Sector

At the national level, private participation in the solid waste sector has been initiated since 1995 through the KLHK's Corporate Performance Rating Program (PROPER). Most of the private participation is only limited to revealing its environmental performance to the public, not in the form of direct involvement in the waste management system (Mediana, 2010). In managing the Bantar Gebang TPST, the DKI Jakarta Government has collaborated with the private sector, namely PT. Godang Tua Jaya (GTJ) and PT. Navigat Organic Energy Indonesia (NOEI), but the contract was terminated in 2016 even though it was supposed to expire in 2023 due to a default by PT Godang Tua Jaya (Carina, 25 November 2015). 
In 2020, DHL DKI Jakarta plans to collaborate with the private sector, namely PT Unilever Indonesia and PT Solusi Bangun Indonesia to manage waste mining in the inactive zone at PTST Bantargebang to be reprocessed as an alternative fuel to replace coal (Patnistik, October 1, 2020) . DHL DKI Jakarta also signed a waste bank construction contract in partnership with PT Tirta Investama to supply premium quality bottles to the Recycling Unit (Yuniar, March 2, 2021).

One of the private actors who play an active role in waste management is Waste4Change which aims to provide solutions to waste problems by providing consultation and research, education and campaigns, as well as collecting and recycling waste (Yuliani, 2018). Waste4Change has collaborated with other actors regarding waste management throughout Indonesia. In handling waste in Jakarta, for example, Waste4Change has collaborated with Nestle Indonesia for a corporate social responsibility (CSR) program to create a Wine Waste Bank (Waste4Change, 2020).

In addition, Waste4Change and the DKI Jakarta Provincial Government are in the Jakarta Less Waste program, which is a competition held for restaurants and buildings to reduce waste. Another method that is often taken by the private sector to carry out CSR in handling waste is in the form of a waste bank. Such as PT Allianz which formed the Environmentally Aware Guntur Waste Bank which involved Allianz employees and the community (Damaledo, 24 March 2020). The same thing was also done by Kompas Gramedia $(\mathrm{KG})$ which carried out development in Kampung Koran together with Salam Rancage. In addition to providing assistance with the procurement of a waste bank, KG has also built a city garden (Sodikin, 22 February 2020).

\section{Conclusion}

a. In meeting the aspects of good environmental governance (GEG), it can be concluded that GEG has not been fully implemented in waste management in DKI Jakarta. GEG's achievements in waste management in Jakarta can be summed up as follows:

b. In the dimension of the rule of law, the DKI Jakarta Provincial Government has fulfilled this dimension with the existence of laws and regulations that regulate waste management, one of which is Perda no. 4 of 2019 concerning Amendments to Regional Regulation no. 3 of 2013 concerning Waste Management. However, the regulation does not improve the waste management system from upstream to downstream.

c. On the dimensions of participation and representation, the government has tried to involve the community by carrying out several programs such as $3 \mathrm{Rs}$ and waste banks. The government also collaborates with the private sector in processing waste. However, their participation still needs to be increased.

d. In the dimension of access to information, it can be seen that one of the causes of low participation among the community is socialization that does not reach the grassroots level and the distribution of information is not evenly distributed.

e. In the dimensions of transparency and accountability, the calculation of the tipping fee as well as all income and expenses borne by the DKI Jakarta Provincial Government needs to be published and accounted for. Currently, there is an Electronic Procurement Service (LPSE) system that facilitates the transparency of the tender process. 
f. Fulfillment in the decentralization dimension can be seen from the waste management carried out by the DKI Jakarta Provincial Government and the regional regulations used to regulate waste problems. The DKI Jakarta Provincial Government has its own institution to deal with the waste problem and does not depend on the center. However, for decentralization that is left to the community, the DKI Jakarta Provincial Government needs to improve the strategies they take in order to achieve integrated and inclusive waste management. Currently, waste management still emphasizes the role of the government.

g. In terms of institutions and institutions, the DKI Jakarta Provincial Government has an Environmental Service (DLH) whose one of its duties is to deal with waste problems. In addition, the DKI Provincial Government also cooperates with other institutions in managing waste, such as the Bekasi City Government. However, there were a number of conflicts between institutions and institutions that played a role.

h. The fulfillment of the aspect of access to obtain justice is still not fully fulfilled because the welfare of all stakeholders who play a role in waste management, especially the scavengers has not been fully paid attention.

\section{References}

[1] Aprilia, A. Tezuka, T. \& Spaargen, G. (2011). Municipal Solid Waste Management with Citizen Participation: An Alternative Solution to Waste Problems in Jakarta, Indonesia. Green Energy and Technology, 66. pp. 56-62. DOI: 10.1007/978-4-431-53910-0_7

[2] Aprilia, A. Tezuka, T. \& Spaargen, G. (2013). Inorganic and hazardous solid waste management: Current status and challenges for Indonesia. Procedia Environmental Sciences, 17. pp. 640 - 647.

[3] Asiyah, N. (2019). Kebijakan Pemerintah Kota Langsa terhadap Pengelolaan Sampah dalam Memenuhi Prinsip Good Environmental Governance. Jurnal Hukum Samudra Keadilan, 14(2). E-ISSN: 2615-7845.

[4] Bryman, A. (2012). Social Research Methods. 4th ed. United States: Oxford University Press Inc. 418.

[5] Handayanti, P. (2016). A Group Approach in a Community Empowerment: A Case Study of Waste Recycling Group in Jakarta. Journal of Education and Practice, 7(29). ISSN 2222-1735.

[6] Krisyanti., Vos, I., \& Prilianti, A. (2020). Pengaruh Kampanye \#PantangPlastik terhadap Sikap Ramah Lingkungan (Survei pada Pengikut Instagram @GreenpeaceID). Jurnal Komunikasi, Media dan Informatika, 9(1). pp. 40-51. DOI: 10.31504/komunika.v9i1.2387

[7] Larasati, N. \& Puspaningtyas, A. (2020). Manajemen Tempat Pengelolaan Sampah Terpadu Bantargebang dengan Konsep Collaborative Governance. Channel Jurnal Komunikasi, 8(1). pp. 69-78. ISSN 2621-2579.

[8] Meutia, A. (2017). Waste Bank: The Strategy and Community-Based Environmental Governance. International Conference 2nd SHIELD. pp. 244-249. ISBN: 978-602-61299-9-4.

[9] Nugraha, A., Sutajahjo, S., \& Amin, A. (2018). Persepsi dan Partisipasi Masyarakat terhadap Pengelolaan Sampah Rumah Tangga Melalui Bank Sampah di Jakarta Selatan. Jurnal Pengelolaan Sumberdaya Alam dan Lingkungan, 8(1). pp. 7-14.

[10] Nugroho, A. (2015). Evaluasi Prinsip Good Environmental Governance (Geg) Dalam Penerapan Kebijakan Pengelolaan Sampah Di Kabupaten Kendal. Jurnal Ilmu Pemerintahan Undip.

[11] Nopiyandri. (2014). Penerapan Prinsip Good Enviromental Governance dalam Rangka Perlindungan dan Pengelolaan Lingkungan Hidup. Jurnal Ilmu Hukum Jambi, 5(2).

[12] Mediana, C. (2010). Development of Waste Management Practices in Indonesia. European Journal of Scientific Research, 40(2). pp. 199-210. ISSN 1450-216X. 
[13] Mulyadin, R., Iqbal, M. \& Ariawan, K. (2018). Konflik Pengelolaan Sampah di DKI Jakarta dan Upaya Mengatasinya. Jurnal Analisis Kebijakan Kehutanan, 15(2). pp. 179-191 p-ISSN: 0216-0897.

[14] Mustagfiroh, U., Ni'mah, L., Sundusiyah, A., Addahlawi, H., \& Hidayatullah, A. (2020). Implementasi Prinsip Good Environmental Governance Dalam Pengelolaan Sampah di Indonesia. Jurnal Ilmu Hukum Lingkungan, 4(2). DOI: http://dx.doi.org/10.24970/bhl.v4i2.106

[15] Permatasari, M. \& Rahdriawan, M. (2013). Kajian Keterlibatan Pemulung di PTST Bantargebang Kota Bekasi. Jurnal Teknik PWK, 2(3). pp. 423-433

[16] Sari, M. \& Rustan, A. (2009). Implementasi Good Governance dalam Pengelolaan Sampah. Jurnal Borneo Administrator, 5(2). DOI: https://doi.org/10.24258/jba.v5i2.45

[17] Sasaki, S., Tetsuya, A., Tambunan, A., \& Prasadja, H. (2014). Household income, living and working conditions of dumpsite waste pickers in Bantar Gebang: Toward integrated waste management in Indonesia. Resources, Conservation and Recycling, 89. pp 11-21.

[18] Sukwika, T. \& Noviana, L. (2020). Status Keberlanjutan Pengelolaan Sampah Terpadu di TPSTBantargebang Bekasi: Menggunakan Rapfish dengan R Statistik. Jurnal Ilmu Lingkungan, 18(1). pp 107-118. ISSN 1829-8907

[19] Verawati, S. \& Tuti, R. (2020). Policy Implementation of Solid Waste Management in South Jakarta. Jurnal Administrasi Publik, 10(2). DOI: https://doi.org/10.31289/jap.v10i2.3107

[20] Yuliani, F. (2018). Pengelolaan Sampah dari Waste4Change terkait Permasalahan Sampah di DKI Jakarta. IJPA The Indonesian Journal of Public Administration, 4(1). ISSN 2460-0369.

[21] Carina, J. (2015, 25 November). Wali Kota Bekasi Dukung jika Ahok Putus Kontrak PT Godang Tua Jaya. Kompas.com. Diperoleh dari https://megapolitan.kompas.com/read/2015/11/25/16395371/Wali.Kota.Bekasi.Dukung.jika.Ahok.Putus .Kontrak.PT.Godang.Tua.Jaya. Diakses 8 April 2021.

[22] Damaledo, Y. D. (2020, 24 Maret). Allianz Peduli Lingkungan Lewat Program CSR Bank Sampah Gusling. Tirto.id. Diperoleh dari https://tirto.id/allianz-peduli-lingkungan-lewat-program-csr-banksampah-gusling-eHly. Diakses 8 April 2021.

[23] Faqih, F. (2014, 27 Februari). Ada indikasi korupsi di pengelolaan sampah TPST Bantargebang. Merdeka.com. Diperoleh dari https://www.merdeka.com/jakarta/ada-indikasi-korupsi-di-pengelolaansampah-tpst-bantargebang.html. Diakses 7 April 2021.

[24] Hana, O. (2021, 23 Februari). Pengolahan Sampah ITF Sunter Dikritik, NasDem: Buang-Buang Anggaran. Bisnis.com. Diperoleh dari https://jakarta.bisnis.com/read/20210223/77/1359596/pengolahansampah-itf-sunter-dikritik-nasdem-buang-buang-anggaran. Diakses 7 April 2021.

[25] Liauw, H. (2014, 1 Maret). Jakarta Kewalahan Mengelola Sampah. Kompas.com. Diperoleh dari https://megapolitan.kompas.com/read/2014/04/01/0831590/Jakarta.Kewalahan.Mengelola.Sampah. Diakses 7 April 2021.

[26] Lova, C. (2019, 13 Agustus). Walhi Minta Pemrov DKI Segera Terapkan Peraturan Pengurangan Sampah Plastik. Diperoleh dari https://megapolitan.kompas.com/read/2019/08/13/06595871/walhi-mintapemrov-dki-segera-terapkan-peraturan-pengurangan-sampah. Diakses 8 April 2021.

[27] Marison, W. (2019, 13 Juni). Tumpukan 7.500 Ton Sampah Per Hari di Jakarta Hampir Setara Besar Candi Borobudur. Kompas.com. Diperoleh dari https://megapolitan.kompas.com/read/2019/06/13/13491691/tumpukan-7500-ton-sampah-per-hari-dijakarta-hampir-setara-besar-candi. Diakses 5 April 2021.

[28] Nugroho, A. (2018, 16 Mei). Warga Bantargebang Tagih Kompensasi yang Belum Cair. Kompas.com. Diperoleh dari https://megapolitan.kompas.com/read/2018/05/16/15502381/warga-bantar-gebang-tagihdana-kompensasi-yang-tak-kunjung-cair. Diakses 10 April 2021.

[29] Patnistik, E. (2020, 1 Oktober). Olah Sampah Bantargebang Jadi Energi Terbarukan, DKI Gandeng Swasta. Kompas.com. Diperoleh dari https://megapolitan.kompas.com/read/2020/10/01/16070371/olahsampah-bantargebang-jadi-energi-terbarukan-dki-gandeng-swasta. Diakses 8 April 2021. 
[30] Prayoga, R. (2019, 25 Agustus). DKI canangkan Gerakan Sampah Tanggung Jawab Bersama. Antaranews.com. Diperoleh dari https://www.antaranews.com/berita/1029212/dki-canangkan-gerakansampah-tanggungjawab-bersama. Diakses 8 April 2021.

[31] Sodikin, A. (2020, 22 Februari). Bank Sampah Kampung Koran Mampu Reduksi 35 Ton Sampah DKI Jakarta. Kompas.com. Diperoleh dari https://megapolitan.kompas.com/read/2020/02/22/14392491/banksampah-kampung-koran-mampu-reduksi-35-ton-sampah-dki-jakarta. Diakses 8 April 2021.

[32] Wiryono, S. (2021, 9 Maret). Pilot Project PLTSa Bantar Gebang, Sulap 9.879 Ton Sampah Jadi Energi Listrik. Kompas.com. Diperoleh dari https://megapolitan.kompas.com/read/2021/03/09/22065281/pilotproject-pltsa-bantar-gebang-sulap-9879-ton-sampah-jadi-energi. Diakses 7 April 2021.

[33] Yuniar, N. (2021, 2 Maret). DKI Jakarta buat kesepakatan kerja sama kembangkan Bank Sampah Induk. Antaranews.com. Diperoleh dari https://www.antaranews.com/berita/2023053/dki-jakarta-buatkesepakatan-kerja-sama-kembangkan-bank-sampah-induk. Diakses 8 April 2021.

[34] Zulfikar, M. (2020, Januari 27). Intip cara Anies kelola sampah di Jakarta. Antaranews.com. Diperoleh dari https://www.antaranews.com/berita/1266839/intip-cara-anies-kelola-sampah-di-jakarta. Diakes 6 April 2021.

[35] Badan Pemeriksa Keuangan RI. (2021, 12 Maret). Pemprov DKI Siap Bangun 4 ITF untuk Kurangi dan Ubah Sampah Jadi Energi. Retrieved form https://jakarta.bpk.go.id/pemprov-dki-siap-bangun-4-itfuntuk-kurangi-dan-ubah-sampah-jadi-energi/. Diakses 7 April 2021.

[36] Brahmanti, G. (2016). Pengelolaan Sampah Oleh Dinas Kebersihan Propinsi Dki Jakarta (Studi: Tempat Pengolahan Sampah Bantargebang (Skripsi). Depok: Universitas Indonesia. Diperoleh dari http://www.lontar.ui.ac.id/naskahringkas/2019-08/S65931-Gita\%20Ayu\%20Brahmanti

[37] Greeneration Indonesia. (2015). Greeneration: Atasi Sampah dengan Masuk RT. https://greeneration.org/en/about-2/\#vision

[38] Indonesian Center for Environment Law. (2019, 21 Mei). Rencana Perubahan dan Perancangan Peraturan Persampahan di DKI Jakarta. Diperoleh dari https://icel.or.id/isu/rencana-perubahan-dan-perancanganperaturan-persampahan-di-dki-jakarta. Diakses 7 April 2021

[39] Waste4Change. (2020, 3 Februari). Waste4Change Launches Community Development (Comdev) Service to Support CSR Program in Waste Management. Diperoleh dari https://waste4change.com/blog/waste4change-launches-community-development-comdev-service-tosupport-csr-program-in-waste-management 
